\title{
The Feldstein-Horioka Puzzle in the Presence of Structural Breaks: Evidence from China
}

\author{
Dilem Yıldırım \\ Department of Economics, Middle East Technical University, Ankara, Turkey \\ E-mail: dilem@metu.edu.tr \\ Phone: + (90) 3122102019
}

Ethem Erdem Orman

Republic of Turkey Prime Ministry Undersecretariat of Treasury, Ankara, Turkey

E-mail: erdem.orman@ hazine.gov.tr

Phone: + (90) 3122046435 


\section{THE FELDSTEIN-HORIOKA PUZZLE \\ IN THE PRESENCE OF STRUCTURAL BREAKS: EVIDENCE FROM CHINA}

\section{DILLEM YILDIRIM}

Department of Economics, Middle East Technical University, 06531, Ankara, TURKEY Email: dilem@metu.edu.tr, Phone: +90 312210 2019, Fax: +(90) 3122107964

\section{ETHEM ERDEM ORMAN}

Republic of Turkey Prime Ministry Undersecretariat of Treasury, 06510, Ankara, TURKEY Email: erdem.orman@hazine.gov.tr, Phone: +90 3122046435 ,Fax: +(90) 3122047487

Corresponding Author: Dilem YILDIRIM, dilem@ metu.edu.tr, phone: +90 3122102019 


\title{
CHINA
}

\begin{abstract}
This study explores the empirical validity of the Feldstein-Horioka puzzle for China in the presence of structural breaks. To this end, we employ the recently proposed multiple-break cointegration test of Maki (2012), along with the one-break Gregory and Hansen (1996) cointegration test. Once the existence of the cointegration between domestic savings and investment is ensured by allowing for endogenous structural breaks, Fully Modified Ordinary Least Squares (FMOLS) and Dynamic Ordinary Least Squares (DOLS) estimation procedures are implemented to obtain reliable inferences from the cointegrating regression. Empirical results reveal that the relationship between Chinese domestic savings and investment has changed with the regime shift towards flexible exchange rates and the 20082009 global financial crises. More specifically, with the introduction of managed floating exchange rate regime, a substantial reduction is observed in the almost unitary saving retention coefficient of the fixed exchange rate period. Furthermore, the correlation has experienced a slight increase since 2009, which coincides with the worldwide protectionist policies adopted in the depth of the global financial crisis.
\end{abstract}

Keywords: Feldstein-Horioka puzzle, saving-investment association, capital mobility, exchange rate regimes, 2008-2009 global financial crises, cointegration, structural breaks, China

JEL classification numbers: E21, E22, F21, C22, C51, G01 


\section{Introduction}

The term 'puzzle' is used by economists to define the case where empirical findings do not confirm the theoretical expectations. One of the most famous puzzles in open economy macroeconomics is the so-called Feldstein-Horioka puzzle, introduced by Feldstein and Horioka (henceforth FH) in 1980. In their seminal paper, FH argue that domestic savings and investment should be perfectly correlated in a closed economy since investments are bound to be solely funded by domestic savings. In an economy with perfect capital mobility, on the other hand, the relationship tends to disappear as domestic investment can be financed by worldwide pool of saving, while domestic saving seeks for global investment opportunities with the highest returns. With this argument, FH conduct a cross-sectional analysis for 16 OECD countries over the period 1960-1974. They observe that domestic savings and investment are strongly correlated and the relation has not weakened over time, suggesting that capital is immobile in the OECD countries. These empirical findings, however, strongly contradict with the situation of perfect capital mobility of industrialized countries, which was achieved via financial market deregulations and liberalization of capital controls. This contradiction was named as the FH puzzle and has raised a great deal of attention among economists.

Since then the FH puzzle has been one of the most explored issues in international finance, with numerous studies attempting to solve the puzzle. Some of these studies, including Summers (1988), Obstfeld and Rogoff (1995), Coakley et al. (1996), and Ho (2003) refuse that high correlation between domestic savings and investment indicates low capital mobility. They argue that exogenous factors like long-run current account solvency constraint, government policies targeting sustainable current account, size of countries, and domestic and global production shocks may breed a strong saving-investment link.

On the other hand, supporting the approach of FH, other studies attempt to explain the puzzling results on methodological and econometric grounds by applying cross-section, panel data or time series estimation procedures. Despite a vast number of investigations (e.g. Frankel et al., 1986; Krol, 1996; Corbin, 2001; Kollias et al., 2008; Murthy, 2009), whether the FH puzzle is valid or not remains largely inconclusive within the cross-sectional or panel data context. Studies, adopting time series methods, mainly focus on the role of policy regime changes. Sarno and Taylor (1998), De Vita and Abbott (2002), Özmen and Parmaksiz (2003a, 2003b), and Mastroyiannis (2007), among others, argue that policy regime changes might introduce structural breaks into the relationship between savings and investment. 
Subsequently, they observe that accounting for those structural breaks weakens or dispels the original strong results of $\mathrm{FH}$.

The objective of this study is to investigate the FH puzzle for the case of China over the period 1970-2013. Given that China is one of the greatest economic success stories having high growth rate, being the world's largest manufacturer, merchandise exporter, and holder of foreign exchange reserves, it is important to examine the link between domestic savings and investment for that country. The main idea behind this study is to uncover the actual saving-investment link in the presence of structural breaks. In this sense, we employ the recently proposed multiple-break cointegration test of Maki (2012), along with the onebreak Gregory-Hansen (1996) cointegration test. To obtain a reliable inference on how the correlation between savings and investment changes with the observed break dates, the cointegrating regression is estimated through the FMOLS approach of Phillips and Hansen (1990) and the DOLS procedure proposed by Stock and Watson (1993).

Roughly, our empirical findings reveal a significant long-run association between China's domestic savings and investment over the study period. Allowing for endogenouslydetermined structural breaks, however, it is observed that the association changes with the introduction of the managed floating exchange rate system and the 2008-2009 global financial crises in a consistent way with economic and financial conditions of China.

The rest of the study is organized as follows. Chapter 2 reviews the empirical literature on the FH puzzle, while Chapter 3 presents a brief overview of the Chinese economy. Chapter 4 describes the data and econometric methodology we implement. Substantive empirical results are discussed in Chapter 5 and finally Chapter 6 concludes the study.

\section{Literature Review}

Given its importance in open economy macroeconomics and policy implications, the FH puzzle has initiated an enormous literature and it is growing with the availability of more sophisticated approaches. ${ }^{1}$

The literature on the FH puzzle has in fact developed in two directions. The first strand of the literature argues that the FH approach of investigating the saving-investment

\footnotetext{
${ }^{1}$ An excellent review of the FH puzzle can be found in Apergis and Tsoumas (2009).
} 
nexus is inappropriate for measuring the degree of capital mobility. This line of research claims that even in models with perfect capital mobility savings and investment could be correlated due to some factors. For example, Sinn (1992), Obstfeld and Rogoff (1995), Coakley et al. (1996), Summers (1988), and Coakley and Kulasi (1997) argue that since the current account balance equals to the difference between savings and investment, a strong correlation between these variables implies nothing but the long-run solvency of current account regardless of the degree of capital mobility. According to this line of research, another reason behind the strong correlation between savings and investment in an economy with high capital mobility is the country-size effect. In this context, Baxter and Crucini (1993), Coakley et al. (1998), and Ho (2003) argue that if the country is large enough to influence interest rates, any increase in national savings will reduce world interest rates and increase investment in that country. Hence, a strong correlation will be observed between savings and investment despite the presence of high capital mobility.

The second strand of the literature supports the approach of FH in measuring capital mobility and attempts to explain the puzzle by adopting various econometric methodologies. Following FH, earlier studies, including Feldstein (1983), Frankel et al. (1986) and Feldstein and Bacchetta (1989) examine the FH puzzle within a cross-sectional framework. However, the finding of a high correlation between saving and investment is almost confirmed for industrial and developing countries even for longer periods.

There are also researchers analyzing the FH puzzle within a panel context. Many of these studies, however, provide a high saving-investment correlation for developed countries which suggests low capital mobility according to the FH approach, e.g. Corbin (2001), Chakrabarti (2006), Adedeji and Thornton (2008), and Pelgrin and Schich (2008). Unlike these studies, Krol (1996) and Kollias et al. (2008) observe a low correlation between domestic saving and investment for 21 OECD countries and the EU15 countries, respectively. The empirical findings of Krol (1996), however, fall under the criticisms of Coiteux and Olivier (2000) and Jansen (2000). They argue that exclusion of Luxembourg from the sample reverses the low correlation finding of Krol (1996) and validates the FH puzzle. On the other hand, Murthy (2009), in a panel of 14 Latin American and 5 Caribbean countries, show that the FH argument is not valid, which is consistent with the recent developments (e.g. increased financial integration, deregulation of banking sector, and weakening of the capital controls) that the sampling countries have witnessed. Similar to Murthy (2009), Kim et al. (2005) and Bangake and Eggoh (2011) observe a low correlation between saving and investment for Asian and African countries, respectively. 
Overall, in a cross-sectional or panel data context, while some researchers conclude that there is no or weak correlation between saving and investment due to high capital mobility, the others fail to provide empirical evidence against the $\mathrm{FH}$ puzzle. According to some economists, cross-sectional and/or panel regressions in the context of FH analysis may entail some problems. For example, Hussein (1998) and Athukorala and Sen (2002), argue that when the saving-investment relationship is modelled by these approaches misleading results may be obtained due to inclusion of economically large and financially developed countries, which can lead to sample selection bias. Furthermore, the saving-investment dynamics may vary country to country due to differences in the structure of an economy, government policies, and country-specific financial shocks. As underlined by Caporale et al. (2005), Narayan (2005a), and Mastroyiannis (2007), ignoring these differences and expecting the saving-investment relationship to be same for the countries in the sample might lead to unreliable inferences on the main question of how much of an increase in savings is truly reflected into domestic investment.

These potential pitfalls have motivated many researchers to examine the savinginvestment relationship for individual countries through time series methods. Given that international capital mobility is a time-varying issue which cannot be correctly specified by one fixed coefficient, as highlighted by Ho (2000) and Telatar et al. (2007), among others, most of these studies account for the possibility that the correlation between savings and investment might be exposed to various policy regime changes and structural breaks. These studies have developed in two directions. While the first strand relies on exogenouslydetermined structural breaks and utilize the standard Engle and Granger cointegration test or the ARDL bounds testing approach to cointegration, the second strand of the studies implements appropriate cointegration tests allowing for endogenous structural breaks. In this sense, Miller (1988), Alexakis and Apergis (1994), and De Vita and Abbott (2002), for example, examines the relationship between the US domestic saving and investment over two subperiods, corresponding to fixed and flexible exchange rate regimes. The results reveal that the US saving-investment correlation weakens after the introduction of the flexible exchange rate regime. Pelagidis and Mastroyiannis (2003) and Mastroyiannis (2007) also consider policy regime changes for Greece and investigate the evolution of the saving-investment correlation through the exogenously-determined subperiods. Their results show that after its accession to the EU, Greece experienced a weaker correlation between saving and investment due to higher degree of capital market integration. These findings are also confirmed by Lemmen and Eijfinger (1995) and Sarno and Taylor (1998) for the UK when 1979 is taken as 
a structural break date, which coincides with abolition of exchange controls and removal of barriers to capital flows. Similarly, Payne (2005) reveals an increase in the capital mobility in Mexico following the 1982 debt crisis.

All of the above-mentioned studies rely on the assumption that the break date is precisely known and examine the saving-investment correlation over the subperiods, designed according to the imposed break date(s). Although the assigned break dates are quite reasonable in an economic sense, such a procedure may suffer from a pre-test bias, as argued by Özmen and Parmaksiz (2003a, 2003b). This argument initiates the second strand of the time series studies, which utilizes cointegration tests allowing for endogenously-determined structural breaks to investigate the FH puzzle.

In this sense, Özmen and Parmaksiz (2003a, 2003b), Narayan and Narayan (2010), Verma and Saleh (2011), and Ketenci (2012) implement the Gregory-Hansen (1996) onebreak cointegration test ${ }^{2}$. While Özmen and Parmaksız (2003a) deduce that the savinginvestment relationship in the UK disappears after the abolishment of foreign exchange controls, Narayan and Narayan (2010) and Verma and Saleh (2011) find no link between saving and investment in G7 countries and Saudi Arabia, respectively. Their results also uncover that the capital mobility in these countries is remarkably stable. Ketenci (2012), however, confirms existence of cointegration between savings and investment in all analyzed 23 EU countries, with the exceptions being Estonia and Portugal. The observed significant but low correlation is assigned to the high capital mobility. The results of Ketenci (2012) also reveal that the correlation between saving and investment could be overestimated if the structural breaks are ignored.

This study aims to explore the FH puzzle for the case of China over the period 19702013. As aforementioned, the existing literature has largely focused on OECD and EU countries, while the saving-investment nexus for China is surprisingly under-studied. To the best of our knowledge, the only papers are Narayan (2005a) and Bordoloi and John (2011). Narayan (2005a) investigates the saving-investment correlation over the subperiods 19521994 and 1952-1998, the former of which represents the period of fixed exchange rate regime. Application of the ARDL bounds test along with the one-break Gregory-Hansen (1996) cointegration test to each subperiods, indicates that domestic savings and investment are strongly correlated in China. Overall, despite a very slight reduction in the correlation with the implementation of the flexible exchange rate regime, empirical findings of Narayan

\footnotetext{
${ }^{2}$ There are also studies investigating the saving-investment relationship in the presence of regime changes through nonlinear models, e.g. Telatar et al. (2007), Kejriwal (2008), and Chen and Shen (2015).
} 
(2005a) validate the FH puzzle for China. Bordoloi and John (2011), on the other hand, explore the relationship between domestic savings and investment for the period 1950-2010 by adopting the ARDL bounds testing approach without considering the possible sensitivity of the relationship to the exchange rate regime shift. According to the results, saving and investment are found to be cointegrated for China. They further investigate the temporal movement of the correlation by recursive estimates using the data for 1997-2009. The results point to a gradual increase in the correlation during the period 1997-2003, which is followed by a decline till 2008 and an increase afterwards with the global financial crisis of 2008-2009.

Similar to Narayan (2005a), our study aims to explore the FH puzzle in the presence of regime changes. Unlike Narayan (2005a), however, we do not impose an assumption that the break date and corresponding subperiods are precisely known. Instead, we utilize the recent multiple-break cointegration test of Maki (2012), along with the Gregory-Hansen (1996) cointegration test to specify the actual date of structural changes. Given that Chinese economy has undergone a number of dramatic changes during our sample period and the Gregory-Hansen (1996) cointegration test has some serious limitations in the presence of multiple breaks, it is important to use a cointegration test allowing for endogenouslydetermined multiple breaks. In this way, the temporal movement of the saving-investment correlation might be analyzed more precisely. Finally, although it is partially investigated by Bordoloi and John (2011) over the sample 1997-2009, the extension of the sample period to 2013 enables us to observe more reliable inference on how the global financial crisis of 20082009 has affected the saving-investment relationship in China.

\section{Chinese Economy}

After the establishment under the leadership of Mao Zedong in 1949, China followed a centrally planned economy until 1979. During the period of 1949-1978, the vast majority of economic output was controlled by the state via setting production targets, controlling prices, and allocating the resources throughout the economy. Private enterprises and foreign investment were not accepted. Foreign trade, on the other hand, was allowed only for the goods which could not be produced in China. Consequently, by 1978 approximately threefourths of industrial production was undertaken by centrally controlled and state-owned enterprises, in line with the centrally planned output targets (Morrison, 2006; Morrison and Labonte, 2013). 
Due to under controlled price and production levels, nonexistence of competition, restricted foreign trade and investment, the Chinese economy was considered as untenable and an overhaul of the whole system was needed by the late 1970s. Accordingly, the Chinese government decided to leave the closed and centrally managed economy in 1978. To raise economic growth and living standards, China initiated its economic reforms in 1979. In this respect, the decentralization of economy was adopted by giving economic control of various enterprises to provincial and local governments. The trade barriers were eliminated and FDI inflows were attracted. Moreover, price controlling of the state on a wide range of products was removed (Rumbaugh and Blancher, 2004; Morrison, 2006, 2014).

Together with the economic reforms that have opened up the Chinese economy to competition and liberalization, its exchange rate policy has also experienced substantial changes over time. The evolution of the exchange rate regime started with the abolishment of administrative exchange rate controls and introduction of dual-exchange rate system in 1981 . In the dual-exchange rate system, the official fixed exchange rate for nontrade related transactions coexisted with a swap market- determined exchange rate for authorized current account transactions. After the implementation of the system, however, a sharp depreciation was observed in the market-determined exchange rate while the fixed rate became relatively overvalued. Therefore, in 1994, the official exchange rate and swap market rate were unified and a managed floating exchange rate system was officially introduced. Afterwards, the exchange rate regime reform was continued further by moving from a managed floating exchange rate pegged to the US dollar towards a basket of currencies in $2005 .^{3}$

With the gradual implementation of economic reforms and exchange rate regime changes, China has experienced a substantial economic growth, as seen in Figure 1. While the real annual GDP growth rate was 6.7 percent on the average for the period 1953-1978, following the introduction of the reforms the growth rate increased to 9.7 percent over the period 1979-1993. In the following two decades, it is observed that the growth rate is still high but almost stable with the rates of $9.2 \%$ and $10.2 \%$ on the average. The unprecedented economic growth of China can also be attributed to its high and rising saving and investment rates (Yang, 2012). Historically, China has high saving rates such that prior to the economic reforms domestic savings as a percentage of the GDP was around 35 percent. Economic reforms, including the decentralization of economic production and removal of the barriers,

\footnotetext{
${ }^{3}$ For more detailed discussion on the evolution of the exchange rate policy of China, see Guijun and Schramm (2003), Huang and Wang (2004).
} 
gave rise to the growth of household and corporate savings, which in turn boosted domestic investment.

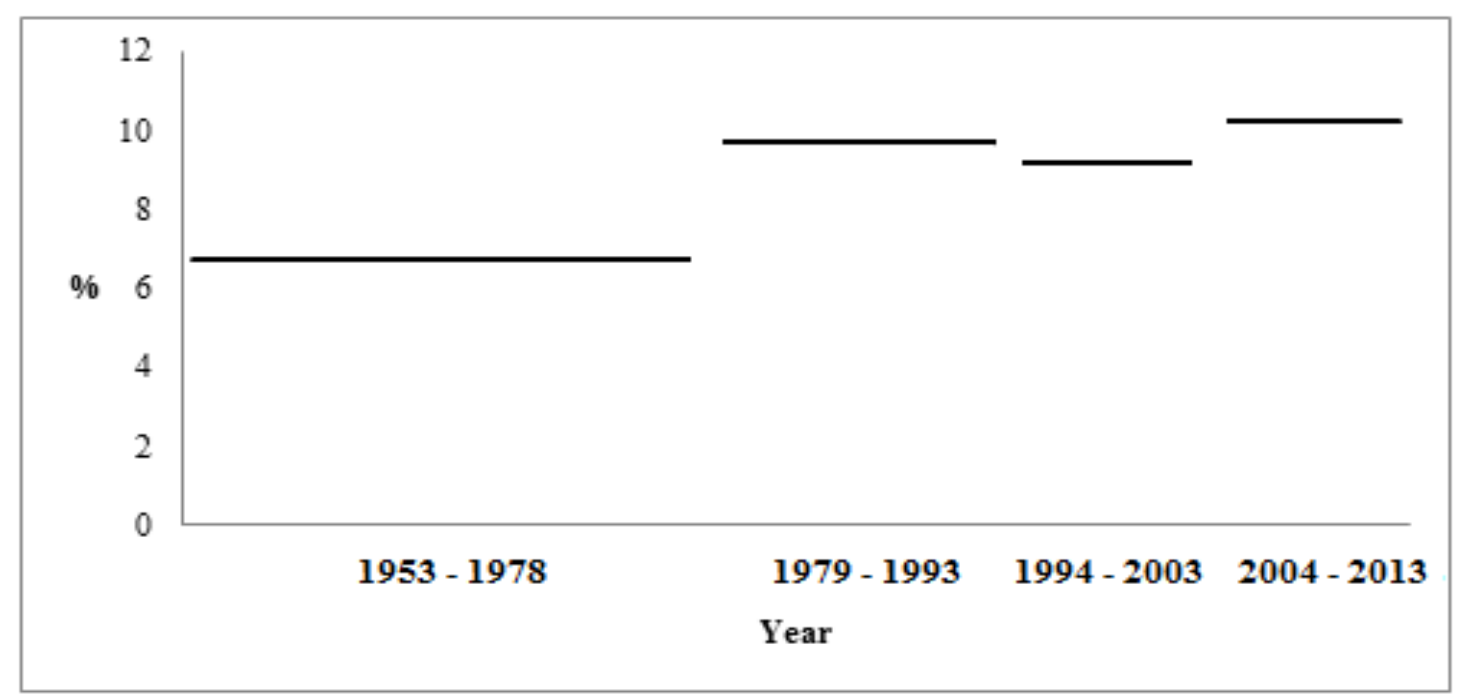

Figure 1: Chinese average real GDP growth rates over the period 1953-2013

Another major factor behind the rapid economic growth of China could be the inward FDI flows. Figure 2 clearly illustrates the increasing trend of annual FDI flows to China. While the total amount of FDI was stable around 2 billion US Dollars over the period 1985-1991, it increased to 127 billion US Dollars by the end of 2013. Currently, China is the world's second-largest recipient of FDI inflows, after the US.

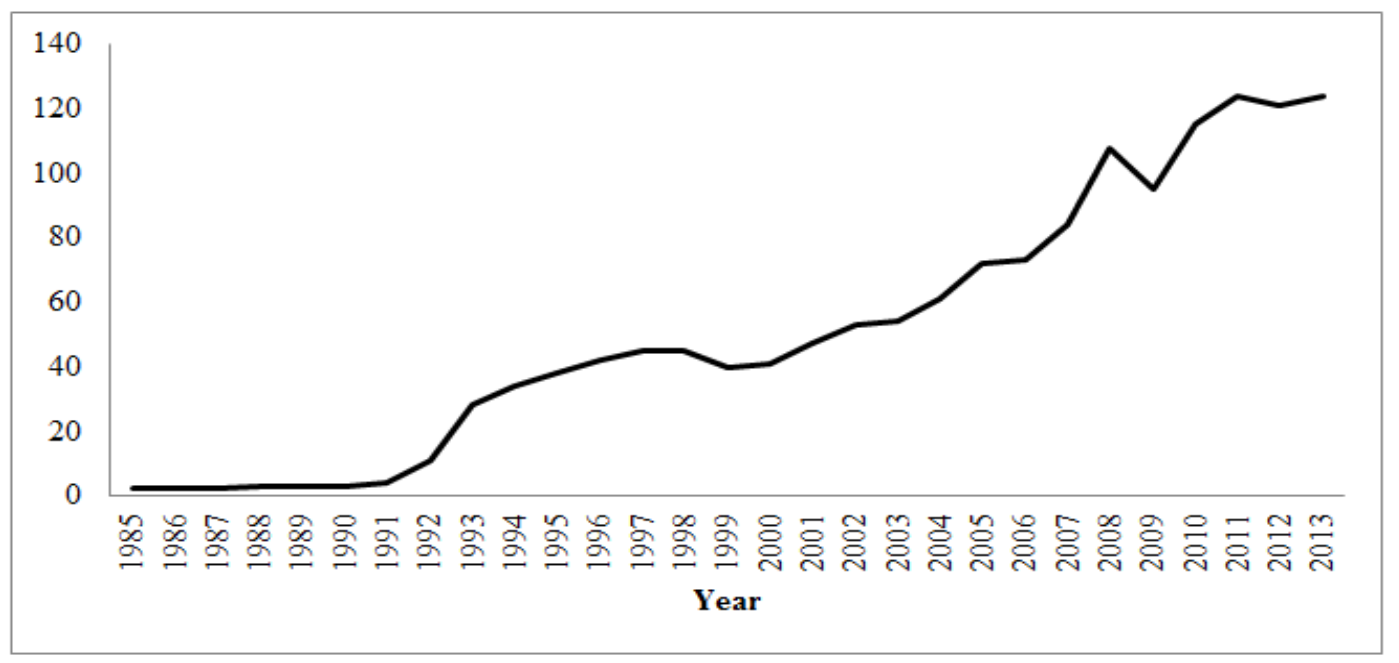

Figure 2: Annual FDI flows to China during the period 1985-2013 ( Billions of US Dollars) 


\section{Methodology}

The modeling approach in this study covers three steps. The first step is to specify the order of integration of the employed series through the unit root tests of Zivot and Andrews (1992) and Lumsdaine and Papell (1997). In the next step, taking the standard Engle-Granger approach as a benchmark, we adopt the cointegration tests proposed by Gregory and Hansen (1996) and Maki (2012). Once cointegration between investment and saving is established by allowing for endogenous structural breaks, our final step is estimating the cointegrating regression.

\subsection{Unit Root Tests}

The first step of cointegration analysis is determination of the integration order of the series. It is known that the ADF and PP tests, the most commonly employed unit root tests in empirical studies, perform relatively well when applied to time series being exposed to no structural break(s). However, as indicated by Perron (1989), these tests are biased towards accepting the false null hypothesis of a unit root when the time series is stationary around a break. On the other hand, Leybourne et al. (1998) demonstrate that if the true DGP is integrated of order one with a break, the standard unit root tests can lead to spurious rejection of the unit root null hypothesis. As mentioned earlier, Chinese economy has undergone some dramatic changes during the sample period of our analysis. Obviously, these changes might have significant impact on investment and saving in China. To account for these changes and propose more reliable results, unit root tests allowing for structural breaks should be utilized. For that reason, we employ Zivot and Andrews (1992) and Lumsdaine and Papell (1997) unit root tests which allow for one and two structural breaks, respectively, to ascertain the order of integration for investment and saving.

\subsubsection{Zivot and Andrews (1992) Unit Root Test}

Zivot and Andrews (1992) develop a unit root testing procedure allowing for one endogenously-determined structural break. They propose three different models. Model A allows for a structural break in the intercept term, model B allows for a structural break in the trend term, and finally model $\mathrm{C}$ combines the first two models and allow for a change in both the intercept and the trend. Model A, B, and C are expressed as follows, respectively: 


$$
\begin{gathered}
\Delta y_{t}=\mu+\alpha y_{t-1}+\beta t+\theta_{1} d u_{t}+\sum_{j=1}^{k} d_{j} \Delta y_{t-j}+\varepsilon_{t} \\
\Delta y_{t}=\mu+\alpha y_{t-1}+\beta t+\gamma_{1} d t_{t}+\sum_{j=1}^{k} d_{j} \Delta y_{t-j}+\varepsilon_{t} \\
\Delta y_{t}=\mu+\alpha y_{t-1}+\beta t+\theta_{1} d u_{t}+\gamma_{1} d t_{t}+\sum_{j=1}^{k} d_{j} \Delta y_{t-j}+\varepsilon_{t}
\end{gathered}
$$

where $y_{t}$ denotes the time series of interest, $\varepsilon_{t}$ is i.i.d. disturbance term with variance $\sigma^{2}, k$ is the augmentation order that ensures the i.i.d. structure of $\varepsilon_{t}, d u_{t}$ is the dummy variable for a mean shift occurring at time $T B$, and $d t_{t}$ is the corresponding trend shift variable defined as:

$$
d u_{t}=\left\{\begin{array}{ll}
1 & \text { if } t>T B \\
0 & \text { otherwise }
\end{array} \quad \text { and } \quad d t_{t}= \begin{cases}t-T B & \text { if } t>T B \\
0 & \text { otherwise }\end{cases}\right.
$$

Implementation of the unit root test of Zivot and Andrews (1992) requires a grid search procedure due to the location of the structural break being unknown. In this respect, the models are estimated by OLS and the $t$-statistic for testing the unit root null hypothesis $(\alpha=0)$ is calculated for each potential structural break $(T B)$, which is in the interval $[0.10 T, 0.90 T]$, where $T$ represents the sample size. For each value of $T B$, the optimal lag length $k$ is determined by using the general to specific approach. The test statistic is then the minimum $t$-statistic over all ADF $t$-statistics and so the selected break date is the one which provides the strongest evidence in favour of stationarity of the time series.

While the asymptotic critical values are provided by Zivot and Andrews (1992), they highlight the fact that with small sample sizes, the distribution of the test statistic may differ substantially from the asymptotic distribution. In order to overcome this problem, they suggest bootstrapping finite sample critical values. In this framework, under the assumption that the errors driving the data series are normal $\operatorname{ARMA}(p, q)$ processes, an $\operatorname{ARMA}(p, q)$ model is estimated for each first difference series of interest $\left(\Delta y_{t}\right)$ with the orders $p$ and $q$ being selected according to the AIC. The estimated ARMA model is then treated as the true DGP. Using the DGP the test statistic is calculated through the aforementioned grid search procedure. Repeating this procedure for 5000 times provides the empirical distribution function of the test statistic and hence the critical values corresponding exactly to our data. 


\subsubsection{Lumsdaine and Papell (1997) Unit Root Test}

By allowing for the possibility of two endogenous structural breaks in level and trend, Lumsdaine and Papell (1997) extend the models A, B, and C of Zivot and Andrews (1992) and propose models $\mathrm{AA}, \mathrm{CA}$, and $\mathrm{CC}$, respectively, as:

$$
\begin{gathered}
\Delta y_{t}=\mu+\alpha y_{t-1}+\beta t+\theta_{1} d u 1_{t}+\theta_{2} d u 2_{t}+\sum_{j=1}^{k} d_{j} \Delta y_{t-j}+\varepsilon_{t} \\
\Delta y_{t}=\mu+\alpha y_{t-1}+\beta t+\theta_{1} d u 1_{t}+\theta_{2} d u 2_{t}+\gamma_{1} d t 1_{t}+\sum_{j=1}^{k} d_{j} \Delta y_{t-j}+\varepsilon_{t} \\
\Delta y_{t}=\mu+\alpha y_{t-1}+\beta t+\theta_{1} d u 1_{t}+\theta_{2} d u 2_{t}+\gamma_{1} d t 1_{t}+\gamma_{2} d t 2_{t}+\sum_{j=1}^{k} d_{j} \Delta y_{t-j}+\varepsilon_{t}
\end{gathered}
$$

where $d u 1_{t}$ and $d u 2_{t}$ are dummy variables for mean shifts, $d t 1_{t}$ and $d t 2_{t}$ are the dummies for trend shifts occurring at times $T B 1$ and $T B 2(T B 2>T B 1+2)$, respectively. That is:

$$
\begin{aligned}
& d u 1_{t}=\left\{\begin{array}{ll}
1 & \text { if } t>T B 1 \\
0 & \text { otherwise }
\end{array} \text { and } \quad d u 2_{t}= \begin{cases}1 & \text { if } t>T B 2 \\
0 & \text { otherwise }\end{cases} \right. \\
& d t 1_{t}=\left\{\begin{array}{ll}
t-T B 1 & \text { if } t>T B 1 \\
0 & \text { otherwise }
\end{array} \text { and } d t 2_{t}= \begin{cases}t-T B 2 & \text { if } t>T B 2 \\
0 & \text { otherwise }\end{cases} \right.
\end{aligned}
$$

In this framework, model AA allows for two breaks in the intercept term, while model CA accounts for two breaks in the intercept and one break in the trend term. The final model CC includes two breaks in the intercept and the trend term.

Similar to the approach of Zivot and Andrews (1992), Lumsdaine and Papell (1997) employ a grid search procedure to test the null hypothesis of a unit root. By ruling out the possibility that the breaks occurred in consecutive dates, the search is conducted for each $T B 1$ and $T B 2$ with $10 \%$ trimming and the augmentation order $k$ being selected according to the general to specific approach. As in Zivot and Andrews (1992), the minimum ADF $t$-statistics (maximum in absolute values) and the break dates that provide the least support for the null of a unit root are selected. Although critical values are provided by Lumsdaine and Papell (1997), we follow the bootstrapping approach of Zivot and Andrews (1992) to circumvent any possible distortion due to using a relatively small sample.

\subsection{Cointegration Tests}

In order to examine the saving-investment link, the standard two-step Engle and Granger procedure requires first estimation of the long-run equilibrium model in the form: 


$$
I_{t}=\alpha+\beta S_{t}+\varepsilon_{t}
$$

where $I_{t}$ is the gross domestic investment as a proportion of GDP, $S_{t}$ is the gross domestic saving as a proportion of GDP, $\alpha$ is the constant, and $\varepsilon_{t}$ is the stochastic disturbance term. In model (5.10), coefficient $\beta$ which is known as 'saving retention coefficient' measures the degree of capital mobility. If a country has perfect international capital mobility, domestic investment can be financed by worldwide pool of saving and the value of $\beta$ approaches to 0 . If the capital is immobile in a country, domestic investment can solely be financed by domestic saving which leads to a unitary saving retention coefficient (Özmen and Parmaksız 2003a). Once the long-run equilibrium model (5.10) is estimated through OLS, the second step of the Engle-Granger approach is testing for cointegration relationship between investment and saving, i.e. stationarity of the $\hat{\varepsilon}_{t}$ sequence.

The long-run equilibrium model of the Engle-Granger approach is formed under the assumption that the cointegrating relationship between savings and investment is subject to no structural changes. However, due to major economic events such as financial and economic crises and shifts in financial system the equilibrium relationship might change, which in turn may affect the reliability of the Engle-Granger cointegration test. Leybourne and Newbold (2003) and Kellard (2006) illustrate that the Engle-Granger test overwhelmingly finds spurious cointegration when the breaks in level and/or slope of independent time series are neglected, whereas Campos et al. (1996) and Gregory et al. (1996) reveal that ignoring the existence of structural breaks leads to substantial decrease in the power of standard cointegration tests. Considering these limitations of the Engle-Granger cointegration test in the presence of structural breaks together with the major structural changes in Chinese economy during our sample period, we proceed with the Gregory and Hansen (1996) cointegration test which accounts for an endogenously-determined structural break.

\subsubsection{Gregory and Hansen (1996) Cointegration Test}

Gregory and Hansen (1996) extend the Engle-Granger approach by allowing a single structural break in the intercept and/or slope coefficients at an unknown time. They propose a residual-based procedure to test the null hypothesis of no cointegration against the alternative hypothesis of cointegration with one structural break. In the spirit of Zivot and Andrews 
(1992), three different models are introduced for the structural change in the cointegrating relationship. The first model is the level shift model (C) which takes the following form:

$$
I_{t}=\alpha_{1}+\alpha_{2} D_{t}+\beta_{1} S_{t}+\varepsilon_{t}
$$

where $D_{t}$ is the dummy variable defined as:

$$
D_{t}= \begin{cases}0 & \text { if } t \leq[T \tau] \\ 1 & \text { if } t>[T \tau]\end{cases}
$$

In this setting, $\alpha_{1}$ is the intercept before the shift, $\alpha_{2}$ is the change in the intercept at the time of the shift. The unknown parameter $\tau$ represents the relative timing of the change, $T$ denotes the sample size, and [ ] denotes the integer part. The second model is the level shift with trend model $(\mathrm{C} / \mathrm{T})$ which takes the form:

$$
I_{l}=\alpha_{1}+\alpha_{2} D_{t}+\gamma t+\beta_{1} S_{t}+\varepsilon_{t}
$$

where $t$ represents a time trend. Finally, the third model is the regime shift model $(\mathrm{C} / \mathrm{S})$, wherein both intercept and slope coefficients are allowed to change as:

$$
I_{\imath}=\alpha_{1}+\alpha_{2} D_{t}+\beta_{1} S_{t}+\beta_{2} S_{t} D_{t}+\varepsilon_{t}
$$

where $\beta_{1}$ is the cointegrating slope coefficient before the regime shift and $\beta_{2}$ is the change in the slope coefficient.

In all three models, a grid search procedure is employed to calculate the test statistic to test the null hypothesis of no cointegration. More specifically, the above models are estimated recursively by allowing the breakpoint to vary such that $[0.10 T] \leq \tau \leq[0.90 T]$. For each value of $\tau$, the residual sequence $\hat{\varepsilon}_{t \tau}$ is obtained through OLS. Once the residuals are obtained, the ADF and Phillips test statistics, $A D F(\tau), Z_{\alpha}(\tau)$, and $Z_{t}(\tau)$ are calculated to test for stationarity of the residuals, i.e. existence of cointegration. ${ }^{4}$ The test statistics of interest, $A D F^{*}, Z_{\alpha}{ }^{*}$, and $Z_{t}^{*}$ are then obtained as:

$$
\begin{aligned}
A D F^{*} & =\inf _{\tau \in T} A D F(\tau) \\
Z_{\alpha}^{*} & =\inf _{\tau \in T} Z_{\alpha}(\tau) \\
Z_{t}^{*} & =\inf _{\tau \in T} Z_{t}(\tau)
\end{aligned}
$$

In this way, the test statistics and the break point which provide the least support for the null of nonstationarity of the residuals and hence no cointegration are chosen. In other words, we

\footnotetext{
${ }^{4}$ For further information about $Z_{\alpha}$ and $Z_{t}$ test statistics, see Phillips (1987).
} 
select the values which provide the strongest evidence in favour of cointegration. The critical values for finite samples are derived through Monte Carlo simulations and tabulated by Gregory and Hansen (1996).

\subsubsection{Maki (2012) Cointegration Test}

While the cointegration test of Gregory and Hansen (1996) performs well when the cointegrating relationship is exposed to a single break, it will be misspecified in the presence of multiple breaks. In this respect, Maki (2012) proposes a new cointegration test that allows for an unknown number of breaks. Four different models depending on whether the changes affect the intercept, the slope or the trend are designed as:

$$
\begin{gathered}
I_{t}=\mu+\sum_{i=1}^{m} \mu_{i} D_{i, t}+\beta S_{t}+\varepsilon_{t} \\
I_{t}=\mu+\sum_{i=1}^{m} \mu_{i} D_{i, t}+\gamma t+\beta S_{t}+\varepsilon_{t} \\
I_{t}=\mu+\sum_{i=1}^{m} \mu_{i} D_{i, t}+\beta S_{t}+\sum_{i=1}^{m} \beta_{i} S_{t} D_{i, t}+\varepsilon_{t} \\
I_{t}=\mu+\sum_{i=1}^{m} \mu_{i} D_{i, t}+\sum_{i=1}^{m} \gamma_{i} t D_{i, t}+\beta S_{t}+\sum_{i=1}^{m} \beta_{i} S_{t} D_{i, t}+\varepsilon_{t}
\end{gathered}
$$

where $\mu_{i}, \beta_{i}$, and $\gamma_{i}$ represent changes in the level, slope and trend coefficients, respectively, $D_{i, t}$ is a dummy variable taking the value of 1 if $t>T B_{i}(i=1, \ldots m)$ and of 0 otherwise, where $m$ is the maximum number of breaks and $T B_{i}$ represents the time period of the break. The first model (5.18) is the level shift model which captures the changes in the intercept. While the second model (5.19) adds a trend term to the level shift model, the third model (5.20), called regime shift model, considers structural breaks occurring both in the intercept and the slope. Finally, the fourth model (5.21) accounts for structural breaks in the intercept, the trend, and the slope terms.

Given the models, the null hypothesis of no cointegration against the alternative hypothesis of cointegration with $i$ number of breaks $(i \leq m)$ is tested by implementing a grid search procedure. The first step of the algorithm of Maki (2012) is setting the maximum number of breaks, $m$. Then, to find the first break, the selected model is estimated for each $T B_{1}$ with $10 \%$ trimming and the residual sequences are obtained. The first break is then selected by minimizing the SSR over these estimations. Using the residual sequences, ADF $t$ statistics for the null of nonstationarity of the residuals, i.e. nonexistence of cointegration, are 
calculated and the minimum $t$-statistic, $\tau_{1}$ is selected. If $i=1$, then $\tau_{1}$ will be the test statistic to test for cointegration with one structural break. If $i=2$, on the other hand, the first break is integrated into the model and the algorithm is pursued with searching for the second break. Imposing $10 \%$ trimming and ruling out the possibility of having breaks in consecutive periods, the model is estimated for each $T B_{2}$ and the residual sequences are derived as before. Then, the second break is chosen to minimize SSR of the estimations. From the residual sequences, the minimum $\mathrm{ADF} t$-statistic, $\tau_{2}$ is obtained. The test statistic to test for cointegration with two structural breaks is then the minimum $t$-statistic over the set $\tau=\tau_{1} \cup \tau_{2}$. This procedure is repeated until $m$ break points are allowed in the cointegrating relationship and the test statistic will be the minimum $t$-statistic over the set of $\tau=\tau_{1} \cup \tau_{2} \cup \ldots \cup \tau_{m}$. The critical values changing with the number of structural breaks allowed in the long-run equation are provided by Maki (2012).

\subsection{Estimation of Long-Run Coefficients}

Once structural breaks are specified and cointegration is established through the cointegration tests of Gregory and Hansen (1996) and Maki (2012), the next step is the construction of the long-run equilibrium model between domestic savings and investment with the structural break dummies.

The application of OLS to a cointegrating equation delivers super-consistent estimators in the presence of cointegration, as shown by Stock (1987). However, the statistical inferences derived from the OLS approach could be unreliable due to the presence of serial correlation and endogenity biases, which do not affect the consistency but induce nonzero mean and nonnormality in the limiting distribution of the test statistics (Vogelsang and Wagner, 2011). To overcome this problem two alternative estimation procedures are proposed. These are the FMOLS estimation approach of Phillips and Hansen (1990) and the DOLS estimation procedure proposed by Stock and Watson (1993). While the FMOLS utilizes a semi-parametric approach to deal with serial correlation and endogenity problems, the DOLS employs a parametric approach by adding leads and lags of the differences of the variables to the long-run regression. Although asymptotically they produce similar results, it is not very clear which one performs better in small samples. In practice, the FMOLS approach is preferable to the DOLS estimation procedure for small samples since it does not 
reduce the degrees of freedom the way parametric approaches like the DOLS do. In our analysis, we will implement both FMOLS and DOLS procedures to derive robust statistical inference on the estimated saving retention coefficient.

\section{Data and Empirical Results}

To explore the existence of the FH puzzle in China we utilize gross domestic saving and gross capital formation as a percentage of GDP. Our data covers the period from 1970 to 2013 which is the widest interval available. This period includes both the gradual transition of the Chinese economy from a command economy to a market-oriented one and the 20082009 global financial crises. As in many other studies investigating the FH puzzle, annual data is employed to avoid seasonality issues. All data is extracted from WDI database of the World Bank.

Taking the standard ADF and PP unit root tests as benchmarks, this chapter discusses first the results of the Zivot and Andrews (1992) one-break and Lumsdaine and Papell (1997) two-break unit root tests. Empirical findings from the cointegration tests of Gregory and Hansen (1996) and Maki (2012) are then described in the subsequent subsection. The final subsection presents the estimated long-run relationship between domestic savings and investment, which accounts for the structural breaks detected by the cointegration tests.

\subsection{Unit Root Test Results}

To investigate the FH puzzle within a cointegration framework, it is essential to establish the nonstationarity of domestic savings and investment. We initially employ two popular conventional unit root tests, ADF and PP. According to the results, both ADF and PP tests do not reject the null hypothesis of a unit root in both of the series at $10 \%$ significance level $^{5}$. Given the low power of the standard ADF and PP tests in the presence of structural breaks, we continue with the unit root tests of Zivot and Andrews (1992) and Lumsdaine and Papell (1997), which allow for one and two endogenous structural breaks, respectively. In both tests, the augmentation order is chosen according to the general to specific approach at the $10 \%$ significance level with a maximum autoregressive order of 4.

\footnotetext{
${ }^{5}$ These results are standard and not presented here. They are available upon request.
} 
As mentioned before, Zivot and Andrews (1992) propose three different models depending on whether the structural change affects the intercept or the trend term. Although there is no consensus has emerged so far regarding on which model is superior, Perron (1989) suggests that most macroeconomic time series could be sufficiently modelled by using model A or model C. Following Perron (1989), many studies (including Narayan, 2005a; Tang and Lean, 2011; Adebola and Dahalan, 2012) employ model A and model C together in their empirical analysis. Being in line with these studies, we conduct the unit root test by estimating the test regressions (5.1) and (5.3), which allow for a change in the intercept (model A) and a change both in the intercept and slope (model C), respectively. Table 1 provides the test results together with the finite sample critical values, simulated through the bootstrap procedure explained in the previous chapter. According to the results, allowing for a one-time structural break provides no additional evidence in favour of stationarity of investment and saving rates. Being consistent with ADF and PP test results, the unit root test of Zivot and Andrews (1992) reveals nonstationarity of the series.

Table 1: Zivot and Andrews Unit Root Test Results

\begin{tabular}{ccccc}
\hline & \multicolumn{2}{c}{ Investment } & \multicolumn{2}{c}{ Saving } \\
\cline { 2 - 5 } & Model $A$ & Model C & Model A & Model C \\
\hline$k B$ & 1996 & 1996 & 2005 & 1998 \\
$t_{\alpha}$ & 1 & 1 & 4 & 4 \\
& -4.319 & -5.034 & -4.245 & -4.974 \\
& $(-4.80)$ & $(-5.08)$ & $(-4.80)$ & $(-5.08)$ \\
& {$[-6.087]$} & {$[-6.574]$} & {$[-6.965]$} & {$[-7.188]$}
\end{tabular}

Notes: $T B$ denotes the structural break date and $k$ indicates the appropriate augmentation order for the test regressions. While the values in parentheses are the asymptotic critical values provided by Zivot and Andrews (1992), exact critical values obtained from 5000 bootstrap replications are given in brackets.

Since the unit root test of Zivot and Andrews (1992) may lose power and deliver misleading results when the series are confronted with more than one break, we proceed with the test of Lumsdaine and Papell (1997). Extending model A and model C of Zivot and Andrews (1992) to model AA and model CC to allow for two endogenous breaks, equations (5.5) and (5.7) are estimated and the test results are reported in Table 2. The results corroborate those obtained from the unit root test of Zivot and Andrews (1992), concluding that both investment and saving rates exhibit nonstationary behavior. 
Table 2: Lumsdaine and Papell Unit Root Test Results

\begin{tabular}{ccccc}
\hline & \multicolumn{2}{c}{ Investment } & \multicolumn{2}{c}{ Saving } \\
\cline { 2 - 5 } & Model AA & Model CC & Model AA & Model CC \\
\hline TB1 & 1988 & 1977 & 1977 & 1977 \\
$k$ & 1996 & 1999 & 2005 & 1998 \\
$t_{\alpha}$ & 1 & 3 & 4 & 4 \\
& -5.064 & -6.284 & -4.960 & -5.772 \\
& $(-6.24)$ & $(-6.82)$ & $(-6.24)$ & $(-6.82)$ \\
& {$[-7.046]$} & {$[-7.714]$} & {$[-8.104]$} & {$[-7.447]$} \\
\hline
\end{tabular}

Notes: $T B 1$ and $T B 2$ denote the structural break dates and $k$ indicates the appropriate augmentation order for the test regressions. While the values in parentheses are the critical values provided by Lumsdaine and Papell (1997), exact critical values obtained from 5000 bootstrap replications are given in brackets.

\subsection{Cointegration Test Results}

Given nonstationarity, I(1) structures of investment and saving, we continue with the cointegration analysis to examine the long-run relationship between investment and saving rates. As such, we commence with the standard Engle and Granger cointegration approach and test for stationarity of the residuals of the long-run equilibrium model (5.10). To allow for a possible structural change in the cointegrating relationship and circumvent the limitations of the Engle-Granger cointegration test in the presence of a structural break, we next apply the Gregory and Hansen (1996) procedure. As discussed before, Gregory and Hansen (1996) suggest three different model specifications, which allow for level shift (5.11), level shift with trend (5.13), and regime shift (5.14). In practice, although there is no consensus on which model is superior, the regime shift model is particularly appropriate to examine the impact of a policy change on the saving-investment link. Thus, being in line with the other studies investigating the FH puzzle under policy changes and structural breaks, we employ the regime shift model $(\mathrm{C} / \mathrm{S})$ for the cointegration analysis. The model (5.14) is estimated and the test statistics $A D F(\tau), Z_{\alpha}(\tau)$, and $Z_{t}(\alpha)$ together with the break points are determined as outlined in the previous chapter.

The results of the Engle-Granger and Gregory-Hansen cointegration tests are presented in Table 3. According to the results, the Engle-Granger test provides evidence for the existence of cointegration between savings and investment at $10 \%$ significance level. Accounting for a possible change in the cointegrating relationship, the Gregory and Hansen test, on the other hand, supports the existence of cointegration based on the ADF statistic 
only if the significance level is extended to 10 percent. The corresponding year of the structural break is found as 1994 . The relatively poor evidences yielded by the cointegration tests of Engle-Granger and Gregory and Hansen (1996) may be due to the presence of the multiple breaks. Based on his Monte Carlo experiments, Maki (2012) reveals that the standard Engle-Granger test and the one-break cointegration test of Gregory and Hansen (1996) are subject to a substantial power loss when the cointegration relationship is exposed to multiple breaks.

Table 3: Engle and Granger and Gregory and Hansen Cointegration Test Results

\begin{tabular}{ccccc}
\hline & Engle-Granger & \multicolumn{3}{c}{ Gregory-Hansen } \\
\hline & $A D F$ & $A D F^{*}$ & $Z_{\alpha}$ & $Z_{t}$ \\
\hline TB & - & 1994 & 1994 & 1994 \\
Test Statistic & $-3.131^{*}$ & $-4.879^{*}$ & -26.074 & -3.969 \\
\hline Critical values & & & & -4.95 \\
\hline $5 \%$ & -3.46 & -4.95 & -47.04 & -4.68 \\
\hline
\end{tabular}

Notes: While $T B$ denotes the structural break date, $(*)$ indicates rejection of the null hypothesis of no cointegration at $10 \%$ significance level.

In order to circumvent any power loss, we proceed with the multiple-break cointegration test of Maki (2012). The test is implemented by estimating the model (5.20), which is a direct extension of the one-break regime shift model of Gregory and Hansen test to multiple breaks. The results are reported in Table $4 . M B_{i}$ indicates the case where the maximum number of breaks is set equal to $i$ where $i=1, . ., 5$. For each case, the previously outlined grid search procedure is implemented to find the test statistics and the break points. It appears that when we allow for one structural break, the test provides evidence for a cointegration relationship being exposed to a change after the year 1993 at 10\% significance level. Integrating the possibility of a second break, on the other hand, leads to a stronger evidence for cointegration with the year of structural breaks being 1993 and 2008. The estimated break points coincide with the exchange rate regime shift from a fixed to a managed floating exchange rate regime and the 2008-2009 global financial crises. Allowing for more than two breaks, however, reveals no further evidence for the existence of cointegration and additional structural breaks. 
Table 4: Maki Cointegration Test Results

\begin{tabular}{cccccc}
\hline & $M B_{1}$ & $M B_{2}$ & $M B_{3}$ & $M B_{4}$ & $M B_{5}$ \\
\hline$T B 1$ & 1993 & 1993 & 1984 & 1984 & 1978 \\
$T B 2$ & - & 2008 & 1993 & 1993 & 1984 \\
$T B 3$ & - & - & 2008 & 2004 & 1993 \\
$T B 4$ & - & - & - & 2008 & 2004 \\
$T B 5$ & - & - & - & - & 2008 \\
Test Statistic & $-4.879 *$ & $-5.453^{* *}$ & -5.358 & -5.651 & -5.852 \\
\hline Critical values & & & & & \\
\hline $5 \%$ & -4.895 & -5.363 & -5.703 & -6.011 & -6.057 \\
$10 \%$ & -4.626 & -5.070 & -5.402 & -5.723 & -6.357 \\
\hline
\end{tabular}

Notes: Critical values are extracted from Maki (2012). $(* *)$ and $(*)$ denote rejection of the null hypothesis of no cointegration at $5 \%$ and $10 \%$ significance levels, respectively.

\subsection{Long-Run Coefficient Estimation Results}

Having established the existence of cointegration, we continue with the estimation of the cointegrating equation (5.20) with the structural break dummies for the years 1993 and 2008 to observe how the detected break points affect the relationship between domestic savings and investment in China. In this sense, we adopt the FMOLS and DOLS estimation procedures, which account for serial correlation and endogenity problems. While FMOLS is performed using the Bartlett Kernel with Newey-West bandwidth, DOLS is implemented with leads and lags determined according to AIC. Table 5 presents estimates of the saving retention coefficient.

Table 5: Estimation of the Saving Retention Coefficient

\begin{tabular}{ccc}
\hline & $D O L S$ & $F M O L S$ \\
\hline$S_{t}$ & $0.970^{* * *}$ & $0.996^{* * * *}$ \\
& $(9.486)$ & $(10.687)$ \\
$D 93_{t} S_{t}$ & $-0.426 * * *$ & $-0.436^{* * *}$ \\
& $(-2.921)$ & $(-3.102)$ \\
$D 08_{t} S_{t}$ & $0.083^{* * *}$ & $0.082^{* * *}$ \\
& $(3.230)$ & $(3.452)$ \\
\hline
\end{tabular}

Notes: Numbers in parentheses denote $t$-statistics and $D 93_{t}$ and $D 08_{t}$ are the impulse dummies taking the value 1 if $(t>1993)$ and $(t>2008)$, respectively, and 0 otherwise. (***) denotes statistical significance of the estimator at $1 \%$ significance level. 
It is seen that the results obtained from the DOLS procedure are almost identical to those of the FMOLS, confirming the robustness of the results ${ }^{6}$. According to the DOLS (FMOLS) the saving retention coefficient is 0.970 (0.996) over the period 1970-1993, which corresponds to the period of fixed exchange rate regime. With this finding it appears that the vast majority of incremental saving is retained within the country to finance the domestic investment. Following the interpretation of $\mathrm{FH}$, this high correlation between investment and saving is an evidence for low capital mobility, which is not surprising given the relatively low FDI in China during the 1970-1993 period, as illustrated in Figure 2. A similar high correlation under fixed exchange rate is also observed by Narayan (2005a) for China.

Over the period of 1994-2008, however, it seems that the relationship between savings and investment has weakened with the saving retention coefficient being equal to 0.544 and 0.560 according to the DOLS and FMOLS procedures, respectively. Given that the regime of fixed exchange rate gave way to the managed floating exchange rate regime in 1994, the substantial decline in the saving retention coefficient is not surprising. As argued by De Paula (2007), the management of fixed exchange rate regime requires capital control system on both inflows and outflows mainly through the prohibitions and quantitative restrictions to protect the country against the risks associated with the fluctuations in international capital movements. Under a flexible exchange rate regime, on the other hand, the restrictions on capital flows across the borders are relaxed, the degree of financial integration with the global economy increases and a broad movement towards liberalization of capital account is observed (Corbin, 2001; Özmen and Parmaks1z, 2003b; De Paula, 2007). Hence, domestic investment could be financed by foreign saving as well, which in turn could induce a substantial decline in the saving retention coefficient, as observed in our case.

Our DOLS (FMOLS) estimation results reveal further an increase in the correlation between savings and investment with the saving retention coefficient being $0.627(0.642)$ after the global financial crisis of 2008-2009. Due to the rapid integration with the world economy and high dependency on the external market, the Chinese economy is quite vulnerable to external shocks. With the global financial crisis of 2008-2009, the country's upward trend of global trade was interrupted due to the dramatic fall in external demand caused by the protectionist measures imposed by the major trade partners, EU countries and the US (Yongding, 2008). To be more specific, Chinese exports plummeted by $16 \%$ from 2008 to 2009, while the FDI flows to China decreased by $12 \%$ within the same period.

\footnotetext{
${ }^{6}$ We checked for the sensitivity of the results to alternative bandwidths and leads and lags, estimates of the coefficients underwent only minor changes, and the major conclusions remained unaltered.
} 
Accordingly, Chinese economic growth rate fell from $14.2 \%$ to $9.2 \%$. To dilute the effects of the global financial crisis, China boosted domestic demand by a massive, investment-heavy stimulus package in conjunction with a vast credit expansion (Burdekin et al., 2012). Furthermore, as a policy response to the financial crisis, the Chinese government implemented various interventions, which involves export restrictions, discriminatory national standards, and restrictions on the cross-border movement of capital (Erixon and Sally, 2010). Given these protectionist policies, it is not surprising to observe an increase in the correlation between Chinese domestic savings and investment. In the existing literature, similar findings are observed by Trunin and Zubarev (2013) for OECD and developing countries and Choudhry et al. (2014) for both EU and non-EU states with the outbreak of the global financial crisis.

Overall, our results suggest that the Chinese economy is in conformity with the FH hypothesis over the 1970-1993 fixed exchange rate period. During the period 1994-2013, however, the FH puzzle exists in a weak form with a low saving retention coefficient, though a slight but significant increase is observed with the global financial crisis of 2008-2009.

\section{Conclusion}

This study investigates the validity of the Feldstein-Horioka puzzle for the case of China over the period between 1970 and 2013. During the study period, the Chinese economy has experienced a fundamental change towards a market-oriented economy with far-reaching reforms including decentralization of economy, trade liberalization, and exchange rate regime changes. Our aim is to account for the possible structural breaks in the saving-investment association arising from those policy changes. In this respect, along with the conventional methodologies, we employ the cointegration tests of Gregory and Hansen (1996) and Maki (2012) to endogenously identify the structural breaks.

Application of the one-break cointegration test of Gregory and Hansen (1996) delivers relatively poor evidence for cointegration between domestic savings and investment. The multiple-break cointegration test of Maki (2012), on the other hand, strongly justifies the existence of cointegration and reveals that the cointegrating relationship has changed twice during the period of study. The first structural break in 1993 coincides with the exchange rate regime shift from a fixed to a managed floating exchange rate regime, while the second structural break in 2008 can be attributed to the 2008-2009 global financial crises. 
Consequent estimation of the cointegrating equation with the observed structural breaks uncovers further that the saving retention coefficient is almost unitary over the 1970-1993 fixed exchange rate period. This finding is quite consistent with the characteristics of the prevailing fixed exchange rate regime and the Feldstein-Horioka hypothesis. With the implementation of the managed floating exchange rate system in 1994, however, it is seen that the relationship between savings and investment has weakened with a substantial decline in the saving retention coefficient. It is not surprising to attain such a result over the period 1994-2008, which is characterized with free capital flows and high financial integration with the global economy. Our results reveal further that the association between saving and investment has experienced a slight increase after 2008, which coincides with the worldwide protectionist policies adopted in the depth of the 2008-2009 global financial crises. To conclude, our empirical findings suggest that the Feldstein-Horioka argument is not a puzzle over the period 1970-1993. However, a weak form of the puzzle still exists during the period 1994-2013.

\section{References}

Adebola, S. S. and Dahalan, J. (2012). "Capital Mobility: An Application of SavingsInvestment Link for Tunisia". International Journal of Economics and Financial Issues, 2, 111 .

Adedeji, O. and Thornton, J. (2008). "International Capital Mobility: Evidence from Panel Cointegration Tests". Economic Letters, 99, 349-352.

Alexakis, P. and Apergis, N. (1994). "The Feldstein-Horioka Puzzle and Exchange Rate Regimes: Evidence from Cointegration Tests". Journal of Policy Modeling, 16, 459-472.

Apergis, N. and Tsoumas, C. (2009). "A Survey of the Feldstein-Horioka Puzzle: What Has Been Done and Where We Stand". Research in Economics, 63, 64-76.

Bangake, C. and Eggoh, J. C. (2011). "The Feldstein-Horioka Puzzle in African Countries: A Panel Cointegration Analysis”. Econometric Modelling, 28, 939-947.

Baxter, M. and Crucini, M. J. (1993). "Explaining Saving-Investment Correlations". The American Economic Review, 83, 416-436.

Bordoloi, S. and John, J. (2011). "Are Saving and Investment Cointegrated? A Cross Country Analysis”. Reserve Bank of India Occasional Papers 32. 
Burdekin, R. C. K., Barth, J. R. and Song, F. M. (2012). "China after the Global Financial Crisis". Economics Research International, 2012, 1-3.

Campos, J., Ericsson, N. R. and Hendry, D. F. (1996). "Cointegration Tests in the Presence of Structural Breaks”. Journal of Econometrics, 70, 187-220.

Caporale, G. M., Panopoulou, E. and Pittis, N. (2005). "The Feldstein-Horioka Puzzle Revisited: A Monte Carlo Study”. Journal of International Money and Finance, 24, 11431149.

Chakrabarti, A. (2006). "The Saving-Investment Relationship Revisited: New Evidence From Multivariate Heterogeneous Panel Cointegration Analyses". Journal of Comparative Economics, 34, 402-419.

Choudhry, T., Jayasekera, R., Kling, G. (2014). "The Global Financial Crisis and the European Single Market: The End of Integration?" Journal of International Money and Finance, 49, 191-196.

Coakley, J. and Kulasi, F. (1997). "Cointegration of Long Span Saving and Investment". Economic Letters, 54, 1-6.

Coakley, J., Kulasi, F. and Smith, R. (1996). "Current Account Solvency and the FeldsteinHorioka Puzzle”. The Economic Journal, 106, 620-627.

Coakley, J., Kulasi, F. and Smith, R. (1998). "The Feldstein-Horioka Puzzle and Capital Mobility: A Review". International Journal of Finance and Economics, 3, 169-188.

Coiteux, M. and Olivier, S. (2000). "The Saving Retention Coefficient in the Long Run and in the Short Run: Evidence From Panel Data". Journal of International Money and Finance, $19,535-548$.

Corbin, A. (2001). "Country Specific Effect in the Feldstein-Horioka Paradox: A Panel Data Analysis”. Economic Letters, 72, 297-302.

De Paula, L. F. (2007). "Financial Liberalisation, Exchange Rate Regime and Economic Performance in BRICs Countries". Economia Internacional, 6, 1-20.

De Vita, G. and Abbott, A. (2002). "Are Saving and Investment Cointegrated? An ARDL Bounds Testing Approach”. Economic Letters, 77, 293-299.

Erixon, F. and Sally, R. (2010). "Trade, Globalisation and Emerging Protectionism Since the Crisis". European Centre for International Political Economy Working Paper 02/2010.

Feldstein, M. (1983). "Domestic Saving and International Capital Movements in the Long Run and the Short Run". European Economic Review, 21, 331-353.

Feldstein, M. and Bacchetta, P. (1989). "National Saving and International Investment". National Bureau of Economic Research Working Paper 3164. 
Feldstein, M. and Horioka, C. (1980). "Domestic Saving and International Capital Flows". The Economic Journal, 90, 314-329.

Frankel, J. A., Dooley, M. and Mathieson, D. (1986). "International Capital Mobility in Developing Countries vs. Industrial Countries: What Do Saving-Investment Correlations Tell Us?". National Bureau of Economic Research Working Paper 2043.

Gregory, A. W. and Hansen, B. E. (1996). "Residual-Based Tests for Cointegration in Models with Regime Shifts". Journal of Econometrics, 70, 99-126.

Gregory, A. W., Nason, J. M. and Watt, D. G. (1996). "Testing for Structural Breaks in Cointegrated Relationships". Journal of Econometrics, 71, 321-341.

Guijun, L. and Schramm, R. M. (2003). “China's Foreign Exchange Policies Since 1979: A Review of Developments and an Assessment". China Economic Review, 14, 246-280.

Ho, T. W. (2000). "Regime-Switching Investment-Saving Correlation and International Capital Mobility”. Applied Economics Letters, 7, 619-622.

Ho, T. W. (2003). "The Saving-Retention Coefficient and Country-Size: The FeldsteinHorioka Puzzle Reconsidered”. Journal of Macroeconomics, 25, 387-396.

Huang, H. and Wang, S. (2004). "Exchange Rate Regimes: China's Experience and Choices". China Economic Review, 15, 336-342.

Hussein, K. A. (1998). "International Capital Mobility in OECD Countries: The FeldsteinHorioka Puzzle Revisited”. Economic Letters, 59, 237-242.

Jansen, W. J. (2000). "International Capital Mobility: Evidence from Panel Data". Journal of International Money and Finance, 19, 507-511.

Kejriwal, M. (2008). "Cointegration with Structural Breaks: An Application to the FeldsteinHorioka Puzzle”. Studies in Nonlinear Dynamics and Econometrics, 12, 1-37.

Kellard, N. (2006). "On the Robustness of Cointegration Tests When Assessing Market Efficiency". Finance Research Letters, 3, 57-64.

Ketenci, N. (2012). "The Feldstein-Horioka Puzzle and Structural Breaks: Evidence From EU Members”. Economic Modelling, 29, 262-270.

Kim, H., Oh, K. and Jeong, C. (2005). "Panel Cointegration Results on International Capital Mobility in Asian Economies". Journal of International Money and Finance, 24, 71-82.

Kollias, C., Mylonidis, N. and Paleologou, S. (2008). "The Feldstein-Horioka Puzzle Across EU Members: Evidence from the ARDL Bounds Approach and Panel Data”. International Review of Economics and Finance, 17, 380-387.

Krol, R. (1996). "International Capital Mobility: Evidence from Panel Data". Journal of International Money and Finance, 15, 467-474. 
Lemmen, J. J. G. and Eijfinger, S. C. W. (1995). "The Quantity Approach to Financial Integration: The Feldstein-Horioka Criterion Revisited". Open Economies Review, 6, 145165.

Leybourne, S. J., Mills, T. C. and Newbold, P. (1998). "Spurious Rejections by Dickey-Fuller Tests in the Presence of a Break under the Null”. Journal of Econometrics, 87, 191-203.

Leybourne, S. J. and Newbold, P. (2003). "Spurious Rejections by Cointegration Tests Induced by Structural Break”. Applied Economics, 35, 1117-1121.

Lumsdaine, R. L. and Papell, D. H. (1997). "Multiple Trend Breaks and the Unit Root Hypothesis", Review of Economics and Statistics, 79, 212-218.

Maki, D. (2012). "Tests for Cointegration Allowing for an Unknown Number of Breaks", Economic Modelling, 29, 2011-2015.

Mastroyiannis, A. (2007). "Current Account Dynamics and the Feldstein and Horioka Puzzle: the Case of Greece". The European Journal of Comparative Economics, 4, 91-99.

Miller, S. M. (1988). “Are Saving and Investment Cointegrated?” Economics Letters, 27, 3134.

Morrison, W. M. (2006). "China's Economic Conditions". Congressional Research Service Report.

Morrison, W. M. (2009). "China and the Global Financial Crisis: Implications for the United States”. Congressional Research Service Report.

Morrison, W. M. (2014). "China's Economic Rise: History, Trends, Challenges, and Implications for the United States". Congressional Research Service Report.

Morrison, W. M. and Labonte, M. (2013). "China's Currency Policy: An Analysis of the Economic Issues". Congressional Research Service Report.

Murthy, N. R. V. (2009). "The Feldstein-Horioka Puzzle in Latin American and Caribbean Countries: A Panel Cointegration Analysis". Journal of Economics and Finance, 33, 176188.

Narayan, P. K. (2005a). "The Saving and Investment Nexus for China: Evidence from Cointegration Tests". Applied Economics, 37, 1979-1990.

Narayan, P. K. (2005b). "The Relationship Between Saving and Investment for Japan". Japan and the World Economy, 17, 293-309.

Narayan, P. K. and Narayan, S. (2010). "Testing for Capital Mobility: New Evidence From a Panel of G7 Countries". Research in International Business and Finance, 24, 15-23.

Obstfeld, M. and Rogoff, K. (1995). "The Intertemporal Approach to the Current Account". Handbook of International Economics, 3, 1731-1799. 
Özmen, E. and Parmaksiz, K. (2003a). "Policy Regime Change and the Feldstein-Horioka Puzzle: the UK Evidence". Journal of Policy Modeling, 25, 137-149.

Özmen, E. and Parmaksiz, K. (2003b). "Exchange Rate Regimes and the Feldstein-Horioka Puzzle: the French Evidence". Applied Economics, 35, 217-222.

Payne, J. E. (2005). "Savings-Investment Dynamics in Mexico". Journal of Policy Modeling, 27, 525-534.

Pelagidis, T. and Mastroyiannis, T. (2003). "The Saving-Investment Correlation in Greece, 1960-1997: Implications for Capital Mobility”. Journal of Policy Modeling, 25, 609-616.

Pelgrin, F. and Schich, S. (2008). "International Capital Mobility: What Do National SavingInvestment Dynamics Tell Us?”. Journal of International Money and Finance, 27, 331-344.

Perron, P. (1989). "The Great Crash, the Oil Price Shock and the Unit Root Hypothesis". Econometrica, 57, 1361-1401.

Phillips, P. C. B. (1987). “Time Series Regression with a Unit Root”. Econometrica, 55, 277301.

Phillips, P. C. B. and Hansen, B. E. (1990). "Statistical Inference in Instrumental Variables Regression with I(1) Processes". Review of Economic Studies, 57, 99-125.

Rumbaugh, T. and Blancher, N. (2004). "International Trade and the Challenges of WTO Accession”. IMF Occasional Paper 232.

Sarno, L. and Taylor, M. P. (1998). "Exchange Controls, International Capital Flows and Saving-Investment Correlations in the UK: An Empirical Investigation". Weltwirtschaftliches Archiv, 134, 69-98.

Sen, A. (2003). "On Unit-Root Tests When the Alternative is a Trend-Break Stationary Process". Journal of Business and Economic Statistics, 21, 174-184.

Sinn, S. (1992). "Saving-Investment Correlations and Capital Mobility: On the Evidence from Annual Data". The Economic Journal, 102, 1162-1170.

Stock, J. H. (1987). "Asymptotic Properties of Least Squares Estimators of Cointegrating Vectors”. Econometrica, 55, 1035-1056.

Stock, J. H. and Watson, M. W. (1993). "A Simple Estimator of Cointegrating Vectors in Higher Order Integrated Systems”. Econometrica, 61, 783-820.

Summers, L. H. (1988). “Tax Policy and International Competitiveness". Chicago University Press, Chicago.

Tang, C. F. and Lean, H. H. (2011). "Revisit Feldstein-Horioka Puzzle: Evidence from Malaysia". Economics Bulletin, 31, 2237-2249. 
Telatar, E., Telatar, F. and Bolatoglu, N. (2007). "A Regime Switching Approach to the Feldstein-Horioka Puzzle: Evidence from Some European Countries". Journal of Policy Modeling, 29, 523-533.

Trunin, P. and Zubarev, A. (2013). "The Feldstein-Horioka Puzzle: Modern Aspects". Ekonomicheskaya Politika, 4, 1-28.

Verma, R. and Saleh, A. S. (2011). "Saving and Investment in Saudi Arabia: An Empricial Analysis". Studies in Economics and Finance, 28, 136-148.

Vogelsang, T. J. and Wagner, M. (2011). "Integrated Modified OLS Estimation and Fixed-b Inference for Cointegrating Regressions". Economic Series, 263, 1-33.

Yongding, Y. (2008). "China's Economic Growth, Global Economic Crisis and China's Policy Responses". The Pakistan Development Review, 47, 337-355.

Zivot, E. and Andrews, D. W. K. (1992). "Further Evidence on the Great Crash, the Oil-Price Shock, and the Unit-Root Hypothesis". Journal of Business and Economic Statistics, 10, 251270 . 